\title{
In vitro culture response of barley (Hordeum vulgare) ethylene synthesis mutant MC 169
}

\author{
Carolina Biagioli* \\ Instituto de Genética "Ewald A. Favret" (IGEAF) \\ CICVyA, INTA. C.C. 25 (1712) Castelar \\ Buenos Aires, Argentina \\ Tel/Fax: 01144500805 \\ E-mail: cbiagioli@cnia.inta.gov.ar \\ Raúl Rios \\ Instituto de Genética "Ewald A. Favret" (IGEAF) \\ CICVyA, INTA. C.C. 25 (1712) Castelar \\ Buenos Aires, Argentina \\ Tel/Fax: 01144500805 \\ E-mail: rrios@cnia.inta.gov.ar \\ Alicia Basso \\ Facultad de Agronomía \\ Universidad de Buenos Aires \\ Av. San Martín 4453 \\ Buenos Aires, Argentina \\ Tel/Fax: (011) 4524-8000 \\ E-mail: abasso@agro.uba.ar \\ Pascual Franzone \\ Instituto de Genética "Ewald A. Favret" (IGEAF) \\ CICVyA, INTA. C.C. 25 (1712) Castelar \\ Buenos Aires, Argentina \\ Tel/Fax: 01144500805 \\ E-mail: pfranzone@cnia.inta.gov.ar \\ Alberto Prina \\ Instituto de Genética "Ewald A. Favret" (IGEAF) \\ CICVyA, INTA. C.C. 25 (1712) Castelar \\ Buenos Aires, Argentina \\ Tel/Fax: 01144500805 \\ E-mail: aprina@cnia.inta.gov.ar
}

Keywords: callus induction, ethylene, habituated calli, hydroponic culture, regeneration.

\author{
Abbreviations: 2,4-D: 2,4 dichlorophenoxyacetic acid \\ $\mathrm{AgNO}_{3}$ : silver nitrate \\ ANA: $\alpha$-naphthaleneacetic-acid \\ AVG: aminoethoxivinilglicine \\ BAP: 6-benzylaminopurine
}

\begin{abstract}
Although it is generally accepted that plant in vitro culture response is influenced by the donor genotype, the genetic and molecular bases of this phenomenon are barely known. As a consequence, the optimization of tissue culture protocols is mainly empirically done. Researchers of the IGEAF studied the genetic basis of the in vitro regeneration of various plant species, including the tissue culture response of artificially induced barley mutants. One barley mutant, MC 169, carries a nuclear gene, recently described controlling the root growth in hydroponic cultivation. Under this
\end{abstract}

condition, the roots of MC 169 mutant plants were longer than those of the original wild type line MC 182, a fact that was associated with a reduced ethylene biosynthesis. On the other hand, it is known that ethylene accumulation is inhibitory for in vitro regeneration of several plant species. In this study, we compared the in vitro culture response of mutant MC 169 with that of its mother line MC 182. The data about induction and regeneration of calli as well as those of habituated calli formation demonstrated that mutant MC 169 and its mother line MC 182 show a similar in vitro behaviour.

*Corresponding author 
Table 1. Callus induction and regeneration for MC 169 and MC 182 explants derived from donor plants cultivated in growth chamber, field or greenhouse.

\begin{tabular}{|c|c|c|c|}
\hline Genotype & Environment & Callus induction (\%) & Regeneration (\%) \\
\hline \multirow{3}{*}{ MC 169 } & Growth chamber & 89.2 & 26 \\
\cline { 2 - 4 } & Field & 81 & 27.7 \\
\cline { 2 - 4 } & Greenhouse & 83.6 & 41 \\
\hline \multirow{3}{*}{ MC 182 } & Growth chamber & 93 & 23.7 \\
\cline { 2 - 4 } & Field & 77.4 & 25 \\
\cline { 2 - 4 } & Greenhouse & 82.6 & 38.7 \\
\hline
\end{tabular}

A barley (Hordeum vulgare) mutant MC 169 was recently described (Martínez et al. 2004). The roots of this mutant have, under hydroponic cultivation, a growth pattern different from that of its mother line MC 182. This response is due to the absence, in the mutant, of the additional ethylene production observed in MC 182 roots under such growing conditions (Martínez et al. 2005). Ethylene biosynthesis is a process that is mediated by two enzymes: ACC synthase and ACC oxidase. Both enzymes are encoded by gene families and regulated by a complex net of environmental and developmental signals responding both to internal and external stimuli (Wang et al. 2002). On the other hand, ethylene production and in vitro response are related processes. Thus, ethylene accumulation inhibits in vitro regeneration in several plant species (Gong and Pua, 2004). It was also observed that the addition in the culture medium of ethylene synthesis inhibitors such as $\mathrm{AgNO}_{3}$ or AVG increases in vitro regeneration in monocots (Purnhauser et al. 1987; Songstad et al.1988) and dicots (Chi et al. 1991; Roustan et al. 1989).

Although it is generally accepted that plant in vitro culture response is influenced by the donor genotype, the genetic and molecular bases of this phenomenon are barely known (Henry et al. 1994). As a consequence, the optimization of tissue culture protocols is mainly empirically done. Researchers of the IGEAF studied the genetic basis of the in vitro regeneration of various plant species (Franzone et al. 1998; Moltrasio et al. 2004), including the tissue culture response of artificially induced barley mutants (Ríos et al. 1994). The aim of this work was to compare in vitro culture response of MC 169 with its mother line MC 182.

\section{MATERIALS AND METHODS}

\section{Plant material}

Donor plants (barley mutant MC 169 and its mother line MC 182) were cultivated in three different environments: growth chamber $\left(16 \mathrm{hrs}\right.$ photoperiod at $\left.19 \pm 2^{\circ} \mathrm{C}\right)$, field
(2004 average temperatures at Castelar experimental field were: June $12^{\circ} \mathrm{C}$, July $10.8^{\circ} \mathrm{C}$, August $12.7^{\circ} \mathrm{C}$, September $14.8^{\circ} \mathrm{C}$, October $16.4^{\circ} \mathrm{C}$, November $18.7^{\circ} \mathrm{C}$ and December $\left.22.4^{\circ} \mathrm{C}\right)$ and greenhouse $\left(20 \pm 7^{\circ} \mathrm{C}\right)$. Plants at field and greenhouse were sown during 2004, in the following dates $(10 / 6,15 / 7,28 / 7$ and 9/9). The soil at Castelar experimental field corresponds to a typical argiudol. In growth chamber and greenhouse the plants were grown in pots containing soil similar to that of the experimental field.

\section{Methods}

Tissue culture was carried out from immature embryos according to Franzone et al. (1998) but with B5 basal medium (Gamborg et al. 1968) instead. Statistical analyses were performed using a chi-square non-parametric test of independence (Sokal and Rohlf, 1969).

\section{RESULTS AND DISCUSSION}

In the first experiment 1262 immature embryos derived from plants grown in growth chamber, field or greenhouse were cultivated in vitro (477 from MC 169 and 785 from MC 182). Selected calli were transferred to regeneration medium (216 from MC 169 and 223 from MC 182). A high percentage of callus induction ( $\mathrm{ca} .85 \%$ ) was observed for both genotypes derived from plants grown in all the environments (Table 1). Non significant differences were observed between genotypes for callus induction $\left(\chi_{(1,}^{2}\right.$ $\left.{ }_{0.05)}: 0.10\right)$. However, significant differences were detected among environments for this trait $\left(\chi_{(2,0.05)}^{2}: 20.73\right)$. The best results were obtained with explants derived from plants cultivated in growth chamber. Non significant differences were observed between genotypes for callus regeneration $\left(\chi_{(1,0.05)}^{2}: 0.30\right)$ but significant differences were detected among environments for this trait $\left(\chi_{(2,0.05)}^{2}: 66.77\right)$, being the best results achieved with explants collected from plants cultivated in the greenhouse. The observed differences, both for callus induction and regeneration, among explants derived from donor plants grown in different environments 
Table 2. Callus induction and regeneration for MC169 and MC 182 explants derived from donor plants cultivated in growth chamber.

\begin{tabular}{|c|c|c|}
\hline Genotype & Callus induction (\%) & Regeneration (\%) \\
\hline MC 169 & 97.08 & 61.17 \\
\hline MC 182 & 95.38 & 67.74 \\
\hline
\end{tabular}

are consistent with the general observation that the choice of the environment where the donor plants are grown is critical in a tissue culture protocol. One of the main reasons for this could be the influence of the environment in the internal hormone balance of the explant (Roca and Mroginski, 1991). On the other hand, habituated calli, i.e. non-regenerant calli with continuous growth in the regeneration medium after successive subcultures, were observed with similar frequencies ( $c a .11 \%$ of nonregenerant calli) for both genotypes $\left(\chi_{(1,0.05)}^{2}: 0.031\right)$.

An additional experiment to further assess tissue culture response of both genotypes was performed using explants derived from growth chamber-derived immature embryos. In this experiment 267 immature embryos were cultivated in vitro (137 from MC 169 and 130 from MC 182). Selected calli were transferred to regeneration medium ( 85 from MC 169 and 82 from MC 182). A high percentage of callus induction ( $c a .96 \%$ ) was observed for both genotypes (Table 2). Non significant differences were observed between genotypes neither for callus induction $\left(\chi_{(1,0.05)}^{2}: 0.53\right)$ nor for callus regeneration $\left(\chi_{(1,0.05)}^{2}: 0.57\right)$. In addition, habituated calli were observed with similar frequencies ( $c$. $43 \%$ of non-regenerant calli) for both genotypes $\left(\chi_{(1,0.05)}^{2}: 0.14\right)$.

The observed in vitro response for both the MC 169 mutant and its mother line MC 182 was similar. It is worthy of mention that the only phenotypic difference between MC 169 and MC 182 known so far is the growth pattern of the roots under hydroponic cultivation. In this situation, the roots of the mother line MC 182 respond to the stress caused by water with an increase of ethylene production whereas this response is not observed in the mutant $\mathrm{MC}$ 169 . On the other hand, it is generally accepted that in vitro culture is an important cause of stress to the explants. However, the results presented herein suggested that the in vitro culture protocol used in this study did not trigger a differential response in ethylene biosynthesis for the analyzed genotypes measurable by the in vitro culture response assessed in this work. The similar behaviour of the mother line and the mutant can be understandable given the complexity of the genetic control of ethylene biosynthesis as well as its regulation during the development and also in response to different environmental stimuli.

\section{REFERENCES}

CHI, G.; PUA E. and GOH, C. Role of ethylene on de novo shoot regeneration from cotyledonary explants of Brassica campestris ssp. Pekinensis (Lour) Olsson in vitro. Plant Physiology, 1991, vol. 96, no. 1, p. 178-183.

FRANZONE, P.; RIOS, R.; PROCOPIUK, A.; DIAZ, D.; ROBREDO, C. and AGUINAGA, A. Genetic analysis of in vitro regeneration in wheat (Triticum aestivum L). Journal of Genetics and Breeding, 1998, vol. 52, no. 3, p. 195-201.

GAMBORG, O.; MILLER, R. and OJIMA, K. Nutrient requirement suspensions cultures of soybean root cells. Experimental Cell Research, 1968, vol. 50, no. 1, p. 151158.

GONG, H. and PUA, E. Identification and expression of genes associated with shoot regeneration from leaf disc explants of mustard (Brassica juncea) in vitro. Plant Science, 2004, vol. 167, no. 6, p. 1191-1201.

HENRY, Y.; VAIN, P. and DE BUYSER, J. Genetic analysis of in vitro plant tissue culture responses and regeneration capacities. Euphytica, 1994, vol. 79, no. 1-2, p. $45-48$.

MARTÍNEZ, A.; FRANZONE, P.; AGUINAGA, A.; POLENTA, G.; MURRAY, R. and PRINA, A. A nuclear gene controlling seminal root growth response to hydroponic cultivation in barley. Environmental and Experimental Botany, 2004, vol. 51, no. 2, p. 133-144.

MARTÍNEZ, A.; LANDAU, A.; GARCÍA, P.; POLENTA, G.; ARIAS, M.; MURRAY, R.; PENSEL, N. and PRINA, A. Two mutants affecting adaptative responses to abiotic stresses in barley seedlings. Czech Journal of Genetics and Plant Breeding, 2005, vol. 41, no. 1, p. 1-10.

MOLTRASIO, R.; ROBREDO, C.; GÓMEZ, M.; DÍAZ PALEO, A.; DÍAZ, D.; RIOS, R. and FRANZONE, P. Alfalfa (Medicago sativa L) somatic embryogenesis: genetic control and introduction of favourable alleles into elite Argentinean germplasm. Plant, Cell, Tissue and Organ Culture, 2004, vol. 77, no. 2, p. 119-124.

PURNHAUSER, L.; MEDGYESY, P.; CZAKÓ, M.; DIX, P. and MARTÓN, L. Stimulation of shoot regeneration in Triticum aestivum and Nicotiana plumbaginifolia Viv. tissue culture using the ethylene inhibitor $\mathrm{AgNO}_{3}$. Plant Cell Reports, 1987, vol. 6, no. 1, p. 1-4.

RIOS, R.; ROBREDO, C.; FRANZONE, P. and PRINA, A. Respuesta al cultivo in vitro de mutantes inducidas de cebada. In: XXV Congreso Argentino de Genética. (28-31, Agosto, 1994, La Plata, Argentina). Sociedad Argentina de Genética, 1994, p. 16.

ROCA, W. and MROGINSKI, L. Establecimiento de cultivos de tejidos vegetales in vitro. In: Cultivo de tejidos en la agricultura. Fundamentos y Aplicaciones. Cali, 
Biagioli, C. et al.

Colombia, Centro Internacional de Agricultura Tropical, 1991, p. 19-41.

ROUSTAN, J.; LATCHE, A. and FALLOT, J. Stimulation of Daucus carota somatic embryogenesis by inhibitors of ethylene synthesis: Cobalt and nickel. Plant Cell Reports, 1989, vol. 8, no. 3, p. 182-185.

SOKAL, R. and ROHLF, J. Biometry. Freeman and Company, San Francisco, USA, 1969, 776 p.

SONGSTAD, D.; DUNCAN, D. and WIDHOLM, J. Effect of 1-aminocyclopropane-1-carboxylic acid, silver nitrate, and norbornadiene on plant regeneration from maize callus culture. Plan Cell Reports, 1988, vol. 7, no. 4, p. 262-265.

WANG, K.; LI, H. and ECKER, J. Ethylene biosynthesis and signaling networks.The Plant Cell, 2002, Supp. 2002, p. S131-S151.

ZUlOAGA, F. and MORRONE, O. Catálogo de plantas vasculares de la Argentina. Missouri Botanical Garden Press. 1999. 1247 p. ISBN 0-915279-65-7. 